\title{
Scenarios for vehicular air pollutant emissions abatement: a case study in Hangzhou, China*
}

\author{
Qing-yu ZHANG, Xin-xing LI, Wei-li TIAN, Ang-yi FU, Wei-fei DU, Cui WANG ${ }^{\dagger *}$ \\ (Department of Environmental Engineering, Ecological Civilization Research Center, Zhejiang University, Hangzhou 310058, China) \\ †E-mail: wangcui198506@163.com \\ Received Jan. 6, 2014; Revision accepted June 9, 2014; Crosschecked Aug. 26, 2014
}

\begin{abstract}
Motor vehicles are the major source of urban air pollution. The abatement of air pollutant emissions is an urgent task for environmental protection. This paper simulated the abatement for carbon monoxide (CO), volatile organic compounds (VOCs), nitrogen oxides $\left(\mathrm{NO}_{x}\right)$, and particular matter $(\mathrm{PM})$ emissions from vehicles under four scenarios in the year 2015 in Hangzhou, China. It was found that the emissions of CO, VOCs, $\mathrm{NO}_{x}$, and PM from vehicles were 440.551, 23.079, 44.255, and 6.532 kt/a in 2010 in Hangzhou, respectively. The vehicle population will increase to over 1.2 million with a $60.7 \%$ growth rate until 2015 (estimated). Based on the scenario analysis, it was found that eliminating substandard vehicles and upgrading vehicle's standards could help reduce $\mathrm{CO}$ and VOCs effectively, while the expected abatement of $\mathrm{NO}_{x}$ and $\mathrm{PM}$ would be offset by the rapid increase in the vehicle numbers. It was also found that integrated measurements, including eliminating substandard vehicles, upgrading vehicle standards, supplying low sulfur oil, and introducing alternative fuel vehicles could simultaneously reduce the four key pollutants. These integrated policies make it possible to reduce $250.197,10.270,1.791$, and $0.335 \mathrm{kt} / \mathrm{a} \mathrm{CO}$, VOCs, $\mathrm{NO}_{x}$, and $\mathrm{PM}$ with $56.79 \%, 44.50 \%, 4.05 \%$, and $5.14 \%$ decrease rates in 2015, respectively, when compared to those in 2010 .
\end{abstract}

Key words: Control policy, Emission abatement, Scenario analysis, Vehicular pollution doi: 10.1631 jzus.A1400013

Document code: A

CLC number: X51

\section{Introduction}

The vehicle population in China has grown rapidly since 1980 . The total number of motor vehicles reached 190 million in 2010 with an annual growth rate of $12.6 \%$ from 1980 to 2010 (SEPA, 2011). However, Chinese per capita ownership of road vehicles, especially passenger cars, is still much lower than that of developed countries and the average world level (Wang H.K. et al., 2011). Some researchers have predicted that the vehicle population

\footnotetext{
ॠCorresponding author

* Project supported by the International S\&T Corporation Program of the Science and Technology Ministry of China (Nos. S2012GR0080 and 2011B13), and the Scientific Environmental Protection Research Program of Zhejiang Province, China

(C) Zhejiang University and Springer-Verlag Berlin Heidelberg 2014
}

of China will increase more than 1470 million by the year 2030 (Zhang et al., 2010; Hao et al., 2011). The rapid vehicle increase has resulted in more and more serious problems (Zhang et al., 2008a), especially the degradation of air quality in urban areas (Saikawa $e t$ al., 2011). For example, carbon monoxide (CO) emission from motor vehicles contributed to $76.5 \%$ and $81.5 \%$ of the total air pollutants in Beijing and Hangzhou, respectively. The contribution rate for nitrogen oxides $\left(\mathrm{NO}_{x}\right)$ increased to $41.5 \%$ and $68.4 \%$ in the aforementioned two cities (Hao et al., 2001, Zhang et al., 2008a). Vehicular $\mathrm{NO}_{x}$, volatile organic compounds (VOCs), and particular matter (PM) emission contributions in the Pearl River Delta Region, China were $79.7 \%, 69.8 \%$, and $77.9 \%$, respectively (Che et al., 2009). In several major cities, haze days have reached more than $30 \%$ for the entire year, some even up to $50 \%$. Therefore, it is extremely 
urgent to reduce the emissions from vehicles. However, the control measurements and the relative benefits are confusing.

Implementing stringent vehicle emission limit standards is a very efficient method for abating emissions from vehicles (Wu et al., 2011). China has ratcheted down the emission limits for its major vehicle categories by implementing the Euro path guidelines since the late 1990s, National-I standard in 2000, National-II standard in 2004, and NationalIII standard in 2007. However, we found that the overall vehicle fleet emission factors reached their peak when implementing National-III due to vehicle deterioration (Zhang et al., 2008b). After implementing the National-IV vehicle emission standard, fleet emission factors can clearly be reduced (Zhang et al., 2008b). Research data from the American Environmental Protection Agency (EPA) indicated that hydrogen carbon (HC), $\mathrm{CO}$, and $\mathrm{NO}_{x}$ emissions were reduced by approximately $7 \%, 8 \%$, and $5 \%$, respectively, when fuel sulfur content was reduced from $327 \mathrm{mg} / \mathrm{kg}$ (similar to the National-III fuel of China) to $49 \mathrm{mg} / \mathrm{kg}$ (similar to the National-IV fuel of China) (EPA, 2001). China has also launched a fuel desulfurization process to improve oil quality. However, the fuel sulfur content reached $150-350 \mathrm{mg} / \mathrm{kg}$ by 2010 because of the limitations of the fuel refinery technology in China. Furthermore, this value only meets the National-III fuel standard, which is still more inferior to developed countries (Feng et al., 2011). Therefore, to only improve oil standards is not enough to reduce motor vehicle emissions in China. Most studies suggested that $10 \%$ of vehicles produced $50 \%-60 \%$ of all vehicular emissions (Beydoun and Guldmann, 2006), so eliminating high emission vehicles can effectively abate vehicle emissions. China started a policy in June 2009 to encourage car owners to eliminate old vehicles, especially the pre-National-I emission standard vehicles. However, the National-I and National-II emission standard vehicles were still primarily the ones which contribute to overall fleet emissions due to their deterioration (Guo et al., 2006). Alternative strategies involving choices of fossil fuelled or low emission vehicles became an important measurement to reduce vehicle pollution (Oxley et al., 2012). For example, it was found that the reduction of $\mathrm{PM}$ and $\mathrm{NO}_{x}$ emissions from compressed natural gas $(\mathrm{CNG})$ buses ranged from $61 \%$ to $80 \%$ and from $12 \%$ to $40 \%$, respectively, which were lower than that of Euro III diesel buses (ICCT, 2009). Battery electric vehicles (BEVs) and hybrid electric vehicles (HEVs) can also help reduce vehicle emissions, especially BEVs in south China ( $\mathrm{Hu}$ et al., 2010). In 2009, the Chinese government initiated a program named "Ten cities and Thousand Vehicles" to introduce alternative energy vehicles, especially BEVs, through government subsidies. However, the large-scale promotion of BEVs is limited by charging stations and other facilities necessary to utilize such vehicles. In summarizing, single control measures cannot be effective in reducing vehicle emissions and integrated management measures must be taken. This paper evaluates vehicle emissions abatement by different integrated measures in a scenario analysis from 2011 to 2015 in the case city of Hangzhou. CO, VOCs, $\mathrm{NO}_{x}$, and PM were chosen as analysis factors and 2010 is selected as the base year. Four scenarios, business as usual (BAU), eliminate substandard vehicle (ESV), high-standard oil replacement (HOR), and alternative energy replacement (AER), were designed to investigate the vehicular emissions reduction potential and to find out the most effective approach. In each scenario, the prospective abatement quantity and reduction rates were evaluated. Finally, the most effective motor vehicle emission reduction policy and the potential management strategies were provided for the government.

\section{Study area}

Hangzhou is a typical mega city in the Yangtze Delta of south China. The urban area of Hangzhou consists of five districts, covering a $3068 \mathrm{~km}^{2}$ area, and has a population of 4.35 million (Fig. 1). In the past decade, the number of vehicles in Hangzhou increased dramatically. By the end of 2010, the urban area of Hangzhou had over 0.69 million vehicles, which is about 2.03 times that the number in 2004 . Recently, the air quality in Hangzhou significantly deteriorated with the increasing number of vehicles.

\section{Methodology}

\subsection{Vehicle number projection}

The long-range energy alternative planning (LEAP) system, developed by the Stockholm 


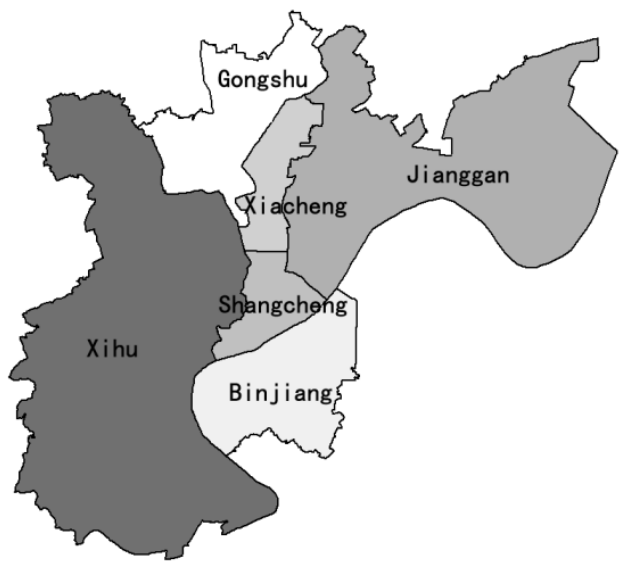

Fig. 1 The map of Hangzhou, China

Environment Institute in 1997, was used for determining the vehicle number predictions in this study (Kumar et al., 2003; SEI-B, 2011). It allows for the prediction to consider future energy demand, environmental development existing technologies, as well as advanced technologies, which may be developed in the future.

Five main categories were utilized in the study: passenger cars (PCs), buses, taxies, light duty trucks (Lts) and heavy duty trucks (Hts).

Eq. (1), used to forecast PCs number from 2011 to 2015 , is a function embedded in the LEAP model that uses per capita gross domestic product (GDP) to forecast per capita vehicle ownership:

$$
\text { Stock }_{i}=\operatorname{Stock}_{i-1} \times f_{i}(\mathrm{GDP}, \theta) \text {, }
$$

where $\mathrm{Stock}_{i}$ means the stock of the PCs in the $i$ th year, $f_{i}$ represents the formulation of vehicle growth with GDP, $i$ is the estimated year, and $\theta$ is the elastic coefficient. The value of $\theta$ in China can be deduced from the economic status since different economic periods determine the pattern of motorization (Nurrohim and Sakugawa, 2005). Thus, by comparing the GDP and GDP growth rate in Hangzhou with other cities, we obtained $\theta$ as 1.1 in our study (Nurrohim and Sakugawa, 2005). To predict the population of PCs in the target year, two driving factors, i.e., annual economic growth rate and annual population growth rate, should be determined. The annual GDP growth rate is defined as $10 \%$, according to 'Hangzhou 12th Five-Year National Economic and Social Develop- ment Plan' (ZJPDRC, 2012). The annual population growth rate is calculated according to the statistical yearbook of Hangzhou from 2004 to 2010.

The vehicle numbers of buses, taxies, Lts, and Hts in the target year were predicated according to the regression functions with the number of vehicles from 2004 to 2010. For all the predicated vehicles, we assumed that the proportional rate of gasoline and diesel vehicles was the same as that in 2010, and then the vehicle numbers of different vehicle types and fuel types were projected during 2011 and 2015 .

\subsection{Definition of vehicle emission control policy scenarios}

In recent years, vehicle emission control regulations and measures have been enacted in Hangzhou, including upgrading vehicle emission standards, introduction of alternative energy vehicles, eliminating high emission vehicles, etc. We will introduce more effective vehicle emission control methods in our scenarios design.

\subsubsection{BAU scenario}

In the BAU scenario, we assume that vehicle emission control regulations are maintained at the current level. No other local vehicle management approach was taken in Hangzhou except for the nationwide motor-vehicle regulations. It was also reported that the National-IV emission standards were performed in China in 2011. Considering the uncertainty of the calculated National-V emission standards, we assumed that all new registered vehicles during 2011 to 2015 meet the National-IV emission standards.

\subsubsection{ESV scenario}

The ESV scenario was established under the BAU scenario. Also, we suppose that all pre-National-I vehicles, all diesel National-I vehicles, all diesel National-II buses, and $50 \%$ of other diesel National-II vehicles will be eliminated by the year 2015. To maintain the total vehicle number, all the eliminated vehicles were replaced by the same types of National-IV emission standard vehicles.

\subsubsection{HOR scenario}

The HOR scenario was set under the ESV scenario. Moreover, we suppose that the urban area of 
Hangzhou will supply high quality oil in 2013 and the sulfur concentration of both gasoline and diesel will decrease to $50 \mathrm{mg} / \mathrm{kg}$. That means oil will meet the National-IV fuel standard after 2013.

\subsubsection{AER scenario}

The AER scenario was under the ESV scenario. Also, the battery electric PCs (BEV-PCs), hybrid electric PCs (HEV-PCs), battery electric taxis (BEV-Taxis), hybrid electric taxis (HEV-Taxis), hybrid electric buses (HEV-Buses), and CNG buses (CNG-Buses) will account for 20\%, 15\%, 10\%, 15\%, $50 \%$, and $30 \%$ of their types (Table 1) by 2015 (estimated), respectively. Because diesel vehicles are mainly eliminated during these years, we assume that diesel vehicles will be replaced by alternative energy vehicles.

\subsection{Emission inventory establishment}

A baseline emission inventory serves as a reference emission level, which can be used to measure emission changes when additional control measures are introduced (Sathaye et al., 2004). To better assess the reduction effect of different vehicle control policies in four scenarios, $\mathrm{CO}, \mathrm{VOCs}, \mathrm{NO}_{x}$, and PM, an emission inventory from vehicles in 2010 was established. The vehicular emission calculation equation is shown as

$$
\begin{aligned}
Q_{i}= & V_{i, j} \times \mathrm{EF}_{i, j, \text { running }} \times \mathrm{VKT}_{i, j} \\
& +V_{i, j} \times \mathrm{EF}_{i, j, \text { start-up }} \times T_{i, j} \times 365,
\end{aligned}
$$

where $Q_{i}$ is the vehicular pollutant emission ( $\left.\mathrm{t} / \mathrm{a}\right) ; i$ is the pollutant type; $j$ is the vehicle type; $V_{i, j}$ is the vehicle number, $\mathrm{EF}_{i, j}$,running is the vehicle running emission factors $(\mathrm{g} / \mathrm{km}) ; \mathrm{EF}_{i, j \text {,start-up }}$ is the vehicle start-up emission factor ( $\mathrm{g} /$ time $)$; $\mathrm{VKT}_{i, j}$ is the annual vehicle kilometer traveled $(\mathrm{km})$; and $T_{i, j}$ is the daily vehicle start-up time.

Vehicle emission factors were calculated by the international vehicle emission (IVE) model which was modified in our previous studies (Guo et al., 2007a; 2007b; 2007c; Zhang et al., 2008b). Vehicle driving distribution and fleet distribution were collected based on road tests carried out on four typical types of streets (expressway, highway, arterial way, and residential way) in the Hangzhou district during 2010, including weekend and weekday tests from
7:00 to 21:00. Finally, the integrated running and start-up emission factors for $\mathrm{CO}, \mathrm{VOCs}, \mathrm{NO}_{x}$, and PM were calculated. Vehicle kilometers traveled (VKT) and daily start-up times were collected from previous study (Zhang et al., 2008b).

In the various scenarios, parameters remain the same as the basic year, excluding emission factors, which were estimated by the modified IVE model. Emission factors of BEVs were set at zero. Additionally, emission factors for HEV-PCs (Li et al., 2009), HEV-Buses (Song et al., 2007), and CNGBuses (Wang A.J. et al., 2011) were obtained from previous studies (Table 2). The VKT and daily start-up times of each vehicle type were assumed to be unchanged in the four scenarios. Then vehicle pollutant emission inventories in 2015 were established by Eq. (2). Finally, the reduction rates were calculated for each scenario to compare with the baseline emission levels.

\section{Results and discussion}

\subsection{Vehicle population prediction}

Fig. 2 illustrated the number of vehicles in the Hangzhou urban area from 2011 to 2015 (estimated). The total number of vehicles increased from 0.773 million in 2011 to 1.241 million in 2015 (estimated), with an annual growth rate at $12.5 \%$. Passage cars, Taxis, Buses, Lts, and Hts will increase from 646.2, $27.7,19.9,55.9$, and 32.8 thousand in 2011 to 976.8 , $81.3,19.6,104.9$, and 58.5 thousand in 2015 (estimated), respectively. The annual growth rate for buses is the highest, which reached $30.9 \%$.

The number of vehicles eliminated and replaced by alternative fuel is shown in Table 3 . It shows that vehicles number will increase to 550.911 thousand from 2011 to 2015 (estimated). About 100.17 thousand vehicles will be eliminated and approximately 118.823 thousand vehicles will be replaced by alternative fuel.

\subsection{Scenario analysis and emission reduction potentials}

The vehicular CO, VOCs, $\mathrm{NO}_{x}$, and PM emission inventory of the baseline year (2010) is illustrated in Fig. 3. The emissions of four vehicular pollutants were 440.551, 23.079, 44.255, and $6.532 \mathrm{kt} / \mathrm{a}$, respectively. 
Table 1 Assumed yearly market share for alternative vehicles

\begin{tabular}{lccccc}
\hline \multirow{2}{*}{ Vehicle type } & \multicolumn{5}{c}{ Market share in new registered vehicles $(\%)$} \\
\cline { 2 - 5 } & 2011 & 2012 & 2013 & 2014 & 2015 \\
\hline BEV-PCs & 8 & 12 & 15 & 17 & 20 \\
HEV-PCs & 2 & 5 & 8 & 12 & 15 \\
BEV-Taxis & 2 & 4 & 6 & 8 & 10 \\
HEV-Taxis & 2 & 5 & 8 & 12 & 15 \\
HEV-Buses & 5 & 15 & 26 & 38 & 50 \\
CNG-Buses & 0 & 5 & 10 & 18 & 30 \\
\hline
\end{tabular}

Table 2 Emission factors of different alternative energy fuel vehicles

\begin{tabular}{lccccc}
\hline \multirow{2}{*}{ Vehicle type } & \multicolumn{5}{c}{ Vehicle emission factor $(\mathrm{g} / \mathrm{km})$} \\
\cline { 2 - 5 } & $\mathrm{CO}$ & VOCs & $\mathrm{NO}_{x}$ & $\mathrm{PM}$ & Reference \\
\hline BEV-PCs & 0 & 0 & 0 & 0 & Li et al., 2009 \\
HEV-PCs & 0.22 & 0.02 & 0.01 & 0 & \\
BEV-Taxis & 0 & 0 & 0 & 0 & Li et al., 2009 \\
HEV-Taxis & 0.22 & 0.02 & 0.01 & 0 & Song et al., 2007 \\
HEV-Buses & 4.05 & 0.19 & 10.38 & 0.14 & Wang A.J. et al., 2011 \\
CNG-Buses & 4.1381 & 0.2495 & 3.2197 & 0.0057 & .
\end{tabular}

Table 3 Assumed increased, eliminated, and new energy vehicle numbers in each scenario

\begin{tabular}{lrrrrrr}
\hline \multirow{2}{*}{ Scenario } & \multicolumn{5}{c}{ Vehicles number } \\
\cline { 2 - 7 } & 2011 & 2012 & \multicolumn{1}{c}{ To13 } & \multicolumn{1}{c}{2014} & \multicolumn{1}{c}{2015} & Total \\
\hline BAU (increased) & 82319 & 95323 & 108387 & 123578 & 141304 & 550911 \\
ESV/HOR/AER (eliminated) & 42246 & 29259 & 19359 & 4653 & 4653 & 100170 \\
AER (new energy) & 10302 & 16626 & 21257 & 29620 & 41019 & 118823 \\
\hline
\end{tabular}

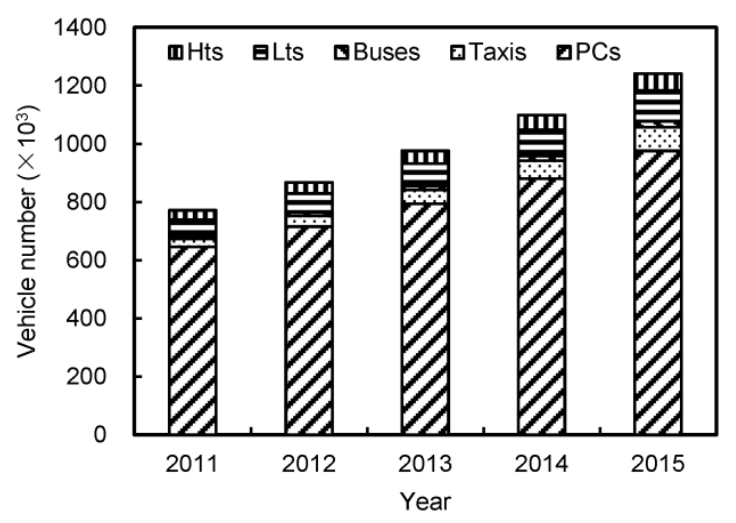

Fig. 2 Predicted number of vehicles in Hangzhou from 2011 to 2015

The emission inventory under BAU, ESV, HOR, and AER scenarios are shown in Fig. 4. In the BAU scenario, $\mathrm{CO}$, VOCs, $\mathrm{NO}_{x}$, and $\mathrm{PM}$ emissions will increase to $475.931,24.883,59.899$, and $7.088 \mathrm{kt} / \mathrm{a}$, respectively. In the ESV scenario, emissions of $\mathrm{CO}$, VOCs, $\mathrm{NO}_{x}$, and PM were predicted to be 415.098, $19.327,48.218$, and $6.862 \mathrm{kt} / \mathrm{a}$, respectively. In the

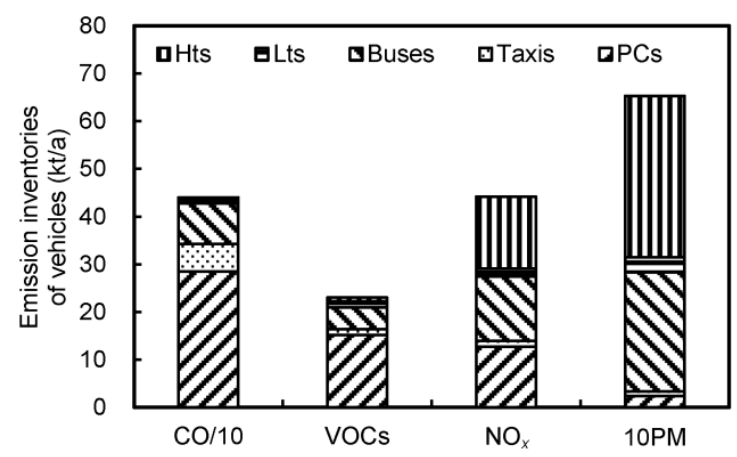

Fig. 3 Vehicle emission inventories of CO, VOCs, $\mathrm{NO}_{x}$, and PM of Hangzhou in 2010

$\mathrm{CO} / 10$ : the amount of CO divided by 10; 10PM: the amounts of PM multiply 10

HOR scenario, the pollutants emissions will be $192.344,12.873,42.822$, and $6.492 \mathrm{kt} / \mathrm{a}$, respectively. The HOR scenario was much more efficient than that of ESV and HOR scenarios. And the pollutants emissions in the AER scenario were similar to that in the HOR scenario, which were predicted to be 190.354, $12.809,42.464$, and $6.196 \mathrm{kt} / \mathrm{a}$, respectively. 
To assess the reduction potentials of abatement policy in each scenario, a summary of the vehicle emission and comparison with the baseline year are presented in Table 4.

Table 4 shows that, in the BAU scenario, vehicular CO, VOCs, $\mathrm{NO}_{x}$, and PM will increase 35.380, $1.804,15.644$, and $0.556 \mathrm{kt} / \mathrm{a}$ from 2010 to 2015 (estimated), with a $8.03 \%, 7.82 \%, 35.35 \%$, and $8.50 \%$ increase rate, respectively. It can be inferred that without any abatement policy, the benefit from an upgraded vehicle standard will quickly be offset by the rapid vehicle increase and deterioration. In the ESV scenario, $\mathrm{CO}$ and VOCs emissions will decrease 25.453 and $3.753 \mathrm{kt} / \mathrm{a}$ with a $5.78 \%$ and $16.26 \%$ decrease rate, respectively, while $\mathrm{NO}_{x}$ and $\mathrm{PM}$ emission

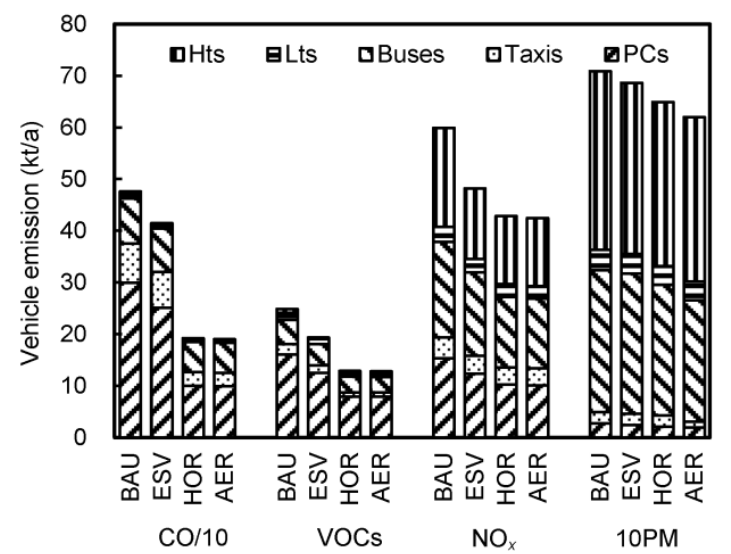

Fig. 4 Predicated vehicle emission inventories of $\mathrm{CO}$, VOCs, $\mathrm{NO}_{x}$, and PM under different scenarios in Hangzhou 2015 (estimated) will increase 3.963 and $0.330 \mathrm{kt} / \mathrm{a}$ with a $8.95 \%$ and $5.05 \%$ increase rate, respectively. It can be concluded that upgrading vehicle standards and eliminating high emission vehicles together will help to reduce the $\mathrm{CO}$ and VOCs emissions, but $\mathrm{NO}_{x}$ and $\mathrm{PM}$ will remain at an increased level. As a result, other management policies should be enacted to reduce the $\mathrm{NO}_{x}$ and $\mathrm{PM}$ emissions from vehicles. In the HOR scenario, vehicular CO, VOCs, $\mathrm{NO}_{x}$, and $\mathrm{PM}$ emissions will reduce $248.207,10.206,1.433$, and $0.040 \mathrm{kt} / \mathrm{a}$ with a $56.34 \%, 44.22 \%, 3.24 \%$, and $0.62 \%$ decrease rate, respectively. In the AER scenario, vehicular CO, VOCs, $\mathrm{NO}_{x}$, and PM emissions will reduce 250.197, $10.270,1.791$, and $0.335 \mathrm{kt} / \mathrm{a}$ with a $56.79 \%, 44.50 \%$, $4.05 \%$, and $5.14 \%$ decrease rate, respectively. The latter two policies will reduce all of the four vehicle emissions effectively.

\subsection{Implication of vehicular pollutants abatement}

Fig. 5 shows that a control policy cannot solely reduce vehicular emissions, because the emission abatement will be offset by a rapid increment of the vehicle population and vehicular deterioration, especially for $\mathrm{NO}_{x}$ and PM. In 2015, it is estimated that upgraded vehicle emission standards and eliminating high emission vehicles all together (ESV scenario) will reduce about $5.78 \% \mathrm{CO}$ and $16.26 \%$ VOCs, respectively. However, $\mathrm{NO}_{x}$ and $\mathrm{PM}$ will still keep increasing when compared to 2010. Under the ESV scenario, improving fuel quality can further reduce all of the four pollutants by $56.34 \%, 44.22 \%, 3.24 \%$, and

Table 4 Summary results of vehicle emission inventories and reduction rates under different scenarios for the target year of 2015 (symbol "_" means emissions will decrease)

\begin{tabular}{clcccc}
\hline Scenario & \multicolumn{1}{c}{ Item } & CO & VOCs & NO $_{x}$ & PM \\
\hline Baseline & Emission inventories in 2010 (kt/a) & 440.551 & 23.079 & 44.255 & 6.532 \\
BAU & Emission inventories in 2015 (kt/a) & 475.931 & 24.883 & 59.899 & 7.088 \\
& Increased emissions (kt/a) & 35.380 & 1.804 & 15.644 & 0.556 \\
& Growth rate (\%) & 8.03 & 7.82 & 35.35 & 8.50 \\
\multirow{2}{*}{ ESV } & Emission inventories in 2015 (kt/a) & 415.098 & 19.327 & 48.218 & 6.862 \\
& Increased missions (kt/a) & -25.453 & -3.753 & 3.963 & 0.330 \\
& Growth rate (\%) & -5.78 & -16.26 & 8.95 & 5.05 \\
HOR & Emission inventories in 2015 (kt/a) & 192.344 & 12.873 & 42.822 & 6.492 \\
& Increased missions (kt/a) & -248.207 & -10.206 & -1.432 & -0.040 \\
& Growth rate (\%) & -56.34 & -44.22 & -3.24 & -0.62 \\
AER & Emission inventories in 2015 (kt/a) & 190.354 & 12.809 & 42.464 & 6.196 \\
& Increased missions (kt/a) & -250.197 & -10.270 & -1.791 & -0.335 \\
& Growth rate (\%) & -56.79 & -44.50 & -4.05 & -5.14 \\
\hline
\end{tabular}


$0.62 \%$ compared to 2010 for $\mathrm{CO}, \mathrm{VOCs}, \mathrm{NO}_{x}$, and PM, respectively. An integrated control policy, including upgrading vehicle emission standards, eliminating substandard vehicles, supplying Nation-IV fuel, and introducing alternative fuel vehicles (e.g., $\mathrm{HEV}, \mathrm{BEV}$, and CNG), will help to effectively reduce vehicle exhausts by $56.79 \%, 44.50 \%, 4.05 \%$, and $5.14 \%$ compared to 2010 for $\mathrm{CO}, \mathrm{VOCs}, \mathrm{NO}_{x}$, and $\mathrm{PM}$, respectively. It also can be concluded that eliminating high emission vehicles and supplying National-IV fuel are the most effective policies to reduce vehicle emissions, especially given the fact that $\mathrm{CO}$ and VOCs reduction potential is bigger than that of $\mathrm{NO}_{x}$ and PM. Previous studies have also reported that alternative energy vehicles replacement can abate $\mathrm{NO}_{x}$ and $\mathrm{PM}$ more effectively than $\mathrm{CO}$ and VOCs (Chae, 2010).

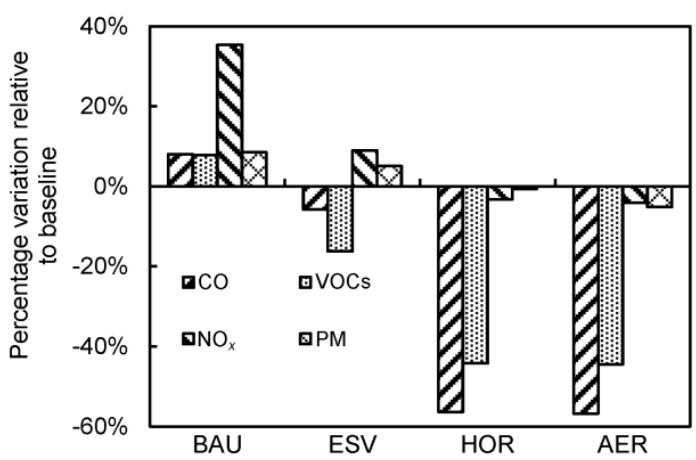

Fig. 5 Variation of vehicular emissions abatement rate for selected scenarios

\section{Conclusions}

The vehicle numbers for Hangzhou will increase to over 1.2 million with a $60.7 \%$ growth rate until 2015 (estimated). The emissions of $\mathrm{CO}, \mathrm{VOCs}, \mathrm{NO}_{x}$, and PM from Hangzhou vehicles were 440.551, $23.079,44.255$, and $6.532 \mathrm{kt} / \mathrm{a}$, respectively, in 2010 . In 2015, it is estimated in a BAU scenario that $\mathrm{CO}$, VOCs, $\mathrm{NO}_{x}$, and $\mathrm{PM}$ emissions from vehicles will increase $8.03 \%, 7.82 \%, 35.35 \%$, and $8.50 \%$ when compared to 2010, respectively. In the ESV scenario, $\mathrm{CO}$ and VOCs emissions will decrease $5.78 \%$ and $16.26 \%$, while $\mathrm{NO}_{x}$ and $\mathrm{PM}$ emissions will increase $8.95 \%$ and $5.05 \%$, respectively. In the HOR scenario, vehicular $\mathrm{CO}$, VOCs, $\mathrm{NO}_{x}$, and $\mathrm{PM}$ emissions will abate $56.34 \%, 44.22 \%, 3.24 \%$, and $0.62 \%$, respectively. An integrated control policy (the AER scenario), including upgrading vehicle emission stand- ards, eliminating substandard vehicles, supplying National-IV standard oil, and introducing alternative fuel vehicles (e.g., HEV, BEV and CNG), will reduce vehicle emissions effectively, with $56.79 \%, 44.50 \%$, $4.05 \%$, and $5.14 \%$ reduction rates for CO, VOCs, $\mathrm{NO}_{x}$, and $\mathrm{PM}$, respectively. These control policies and measures can also be used in other cities of China to abate vehicle emissions and achieve air quality improvements. Considering that $\mathrm{NO}_{x}$ and PM emissions from vehicles are still very high, other policies, such as developing public traffic and limiting vehicle numbers, should be implemented as early as possible.

\section{References}

Beydoun, M., Guldmann, J.M., 2006. Vehicle characteristics and emissions: logit and regression analyses of $\mathrm{I} / \mathrm{M}$ data from Massachusetts, Maryland, and Illinois. Transportation Research Part D: Transport and Environment, 11(1):59-76. [doi:10.1016/j.trd.2005.09.003]

Chae, Y., 2010. Co-benefit analysis of an air quality management plan and greenhouse gas reduction strategies in the Seoul metropolitan area. Environmental Science \& Policy, 13(3):205-216. [doi:10.1016/j.envsci.2010.01.003]

Che, W.W., Zheng, J.Y., Zhong, L.J., 2009. Vehicle exhausts emission characteristics and contributions in the Pearl River Delta Region. Research of Environmental Sciences, 22:456-461 (in Chinese).

EPA (Environmental Protection Agency), 2001. Fuel sulfur effects on exhaust emissions, recommendations for MOBILE6, EPA 420-R-01-039, USA. Available from http://www.epa.gov/OMSWWW/models/mobile6/m6tech. htm.

Feng, S., He, H., Sharpe, B., et al., 2011. Overview of China's vehicle emission control program past successes and future prospects. Available from http://www.theicct.org/ sites/default/files/3_NVstandards.pdf.

Guo, H., Zhang, Q.Y., Shi, Y., et al., 2006. Characterization of on-road $\mathrm{CO}, \mathrm{HC}$ and $\mathrm{NO}$ emissions for petrol vehicle fleet in China city. Journal of Zhejiang University-SCIENCE B, 7(7):532-541. [doi:10.1631/jzus.2006.B0532]

Guo, H., Zhang, Q.Y., Shi, Y., et al., 2007a. Estimation of motor vehicle air toxic emissions in urban area of Hangzhou, China. Journal of Zhejiang University (Engineering Science), 41:1223-1228 (in Chinese).

Guo, H., Zhang, Q.Y., Shi, Y., et al., 2007b. Evaluation of the international vehicle emission (IVE) model with on-road remote sensing measurements. Journal of Environmental Sciences, 19(7):818-826. [doi:10.1016/S1001-0742(07) 60137-5]

Guo, H., Zhang, Q.Y., Shi, Y., et al., 2007c. On-road remote sensing measurements and fuel-based motor vehicle emission inventory in Hangzhou, China. Atmospheric Environment, 41(14):3095-3107. [doi:10.1016/j.atmosenv. 2006.11.045]

Hao, H., Wang, H., Yi, R., 2011. Hybrid modeling of China's vehicle ownership and projection through 2050. Energy, 36(2):1351-1361. [doi:10.1016/j.energy.2010.10.055]

Hao, J., Wu, Y., Fu, L., et al., 2001. Motor vehicle source contributions to air pollutants in Beijing. Environmental 
Science, 22:1-6.

Hu, X.J., Chang, S.Y., Li, J.J., et al., 2010. Energy for sustainable road transportation in China: challenges, initiatives and policy implications. Energy, 35(11):4289-4301. [doi:10.1016/j.energy.2009.05.024]

ICCT (International Council on Clean Transportation), 2009. EU 2020 Vehicle Targets. Available from http://www. theicct.org/spotlight/eu-2020-vehicle-targets [Accessed on Feb. 12, 2014].

Kumar, A., Bhattacharya, S., Pham, H., 2003. Greenhouse gas mitigation potential of biomass energy technologies in Vietnam using the long range energy alternative planning system model. Energy, 28(7):627-654. [doi:10.1016/ S0360-5442(02)00157-3]

Li, M.L., Nie, Y.X., Guo, X.X., 2009. Emission test and comparison between hybrid electric bus and conventional bus. Automobile Technology, 2009(10):51-54 (in Chinese).

Nurrohim, A., Sakugawa, H., 2005. Fuel-based inventory of $\mathrm{NO}_{x}$ and $\mathrm{SO}_{2}$ emission from motor vehicles in the Hiroshima Prefecture, Japan. Applied Energy, 80(3):291-305. [doi:10.1016/j.apenergy.2004.04.003]

Oxley, T., Elshkaki, A., Kwiatkowski, A., et al., 2012. Pollution abatement from road transport cross-sectoral implications, climate co-benefits and behavioral change. Environmental Science \& Policy, 19-20:16-32. [doi:10. 1016/j.envsci.2012.01.004]

Saikawa, E., Kurokawa, J., Takigawa, M., 2011. The impact of China's vehicle emissions on regional air quality in 2000 and 2020: a scenario analysis. Atmospheric Chemistry and Physics, 11(18):9465-9484. [doi:10.5194/acp-119465-2011]

Sathaye, J., Murtisshaw, S., Price, L., 2004. Multi project baselines for evaluation of electric power projects. Energy Policy, 32(11):1303-1317. [doi:10.1016/S03014215(03)00098-3]

SEI-B (Stockholm Environment Institute-B), 2011. Long-range energy alternatives planning system user guide. Available from http://sei-us.org/leap/ [Accessed on Feb. 12, 2014].
SEPA (State Environmental Protection Administration of China), 2011. China vehicle emission control annual report. Available from http://www.zhb.gov.cn/gkml/ $\mathrm{hbb} / \mathrm{qt} / 201112 / \mathrm{t} 20111219$ 221495.htm [Accessed on Feb. 12, 2014] (in Chinese).

Song, G., Yu, L., Mo, F., et al., 2007. A comparative environmental study on the emissions of HEV and conventional gasoline vehicle. Automotive Engineering, 29: 865-869 (in Chinese).

Wang, A.J., Ge, Y.S., Tan, J.W., et al., 2011. On-road pollutant emission and fuel consumption characteristics of buses in Beijing. Journal of Environmental Sciences, 23(3):419-426. [doi:10.1016/S1001-0742(10)60426-3]

Wang, H.K., Fu, L.X., Bi, J., 2011. $\mathrm{CO}_{2}$ and pollutant emissions from passenger cars in China. Energy Policy, 39(5): 3005-3011. [doi:10.1016/j.enpol.2011.03.013]

Wu, Y., Wang, R.J., Zhou, Y., et al., 2011. On-road vehicle emission control in Beijing: past, present, and future. Environmental Science \& Technology, 45(1):147-153. [doi:10.1021/es1014289]

Zhang, Q.Y., Wei, Y.M., Tian, W.Y., et al., 2008a. GIS-based emission inventories of urban scale: a case study of Hangzhou, China. Atmospheric Environment, 42(20): 5150-5165. [doi:10.1016/j.atmosenv.2008.02.012]

Zhang, Q.Y., Xu, J.F., Wang, G., et al., 2008b. Vehicle emission inventories projection based on dynamic emission factors: a case study of Hangzhou, China. Atmospheric Environment, 42(20):4989-5002. [doi:10.1016/j.atmosenv. 2008.02.010]

Zhang, Q.Y., Tian, W.L., Zheng, Y.Y., et al., 2010. Fuel consumption from vehicles of China until 2030 in energy scenarios. Energy Policy, 38(11):6860-6867. [doi:10. 1016/j.enpol.2010.06.058]

ZJPDRC (Zhejiang Province Development and Reform Commission), 2012. Hangzhou 12th Five-Year National Economic and Social Development Plan. Available from http://www.zjdpc.gov.cn/art/2012/10/30/art_95_363287. html [Accessed on Feb. 20, 2014] (in Chinese).

\section{中文㩯要:}

\section{本文题目：杭州市机动车污染物排放的减排情景研究}

Scenarios for vehicular air pollutant emissions abatement: a case study in Hangzhou, China

研究目的：预测机动车保有量；根据机动车污染特征，预测机动车污染物排放量；评估不同管理措施下 机动车污染物的削减效果。

创新要点: 综合不同管理措施, 整合评价多种管理措施并行条件下, 机动车污染物排放量的削减情况。

研究方法: 通过长期能源替代计划 (LEAP) 模型对机动车保有量进行预测, 相关排放因子采用校正的能 源替代（AER）模型进行估算。最后设计四个情景模式，评估不同情景的减排效果，并与基 础情景进行对比。

重要结论: 1 . 至 2015 年杭州市机动车将增长 $60.7 \%$ 。2. 淘汰超标机动车和提高机动车污染排放标准能有 效控制 CO 和 VOCs, 而对 $\mathrm{NO}_{x}$ 和 PM 的总量削减效果不明显。3. 采用多种控制手段，如淘 汰劣化超标机动车、提高机动车排放标准、提供低硫代燃油及引进能源替换型机动车将大大 减少机动车污染物的排放量。

关键词组: 削控策略; 减排; 情景分析; 机动车保有量 